\title{
Reaction of Five Non-cereal Grasses to Five Races and Two Host Selective Tox- ins of Pyrenophora tritici-repentis
}

\author{
Shaukat Ali* and M. A. C. Langham \\ Department of Plant Science, South Dakota State University, Brookings, SD 57007, USA \\ (Received on February 24, 2015; Revised on Apri 23, 2015; Accepted on May 10, 2015)
}

\begin{abstract}
Alternative hosts increase the difficulty of disease management in crops because these alternate hosts provide additional sources of primary inoculum or refuges for diversity in the pathogen gene pool. Agropyron cristatum (crested wheatgrass), Bromus inermis (smooth bromegrass), Pascopyrum smithii (western wheatgrass), Stipa viridula (green needlegrass), and Thinopyrum intermedium (intermediate wheatgrass), commonly identified in range, prairie, verge, and soil reclamation habitats, serve as additional hosts for Pyrenophora tritici-repentis, the cause of tan spot in wheat (Triticum aestivum $\mathrm{L}$.). $A$. cristatum (five lines), B. inermis (seven lines), $P$. smithii (four lines), $S$. viridula (two lines), and $T$. intermedium (six lines) were tested for their reactions to 30 representative $P$. tritici-repentis isolates from races 1-5. Plants were grown until the two-three-leaf stage in a greenhouse, inoculated individually with the $\mathbf{3 0}$ isolates, held at high humidity for $\mathbf{2 4} \mathrm{h}$, and rated after $\mathbf{7}$ days. All lines developed lesion types 1-2 (resistant) based on a 1-5 rating scale. Also, leaves from an additional plant set were infiltrated with two host selective toxins, Ptr ToxA as a pure preparation and Ptr ToxB as a dilute crude culture filtrate. All lines were insensitive to the toxins. Results indicate that these grass hosts have a limited or nonsignificant role in tan spot epidemiology on wheat in the northern Great Plains. Additionally, the resistant reactions demonstrated by the grass species in this research indicate the presence of resistance genes that can be valuable to wheat breeding programs for improving wheat resistance to $P$. tritici-repentis.
\end{abstract}

Keywords : alternative host, host-selective effectors, phytotoxins, yellow leaf spot

\footnotetext{
*Corresponding author.

Phone) +1-605-688-6996, FAX) +1-605-688-4452

E-mail)shaukat.ali@sdstate.edu
}

Alternative hosts for plant pathogens are plant species that can be parasitized by a pathogen in addition to its principal economic host (Dinoor, 1974). Alternative hosts can be as advantageous to a plant pathogen as its primary host. They can serve as a bridge between the two growing seasons to enhance pathogen survival, a source of primary inoculum infecting the next season's crop, and alter fungal race structure or provide sources of genetic variability by maintaining different pathogen subpopulations than that established on the primary host. In contrast, alternative hosts potentially provide good sources of resistant genes for breeding crops with superior host plant resistance. The wheat stem rust resistance genes, $\mathrm{Sr} 26$ and $\mathrm{Sr}$ 17, are examples of genes obtained from a wild relative and utilized in wheat (Triticum aestivum L.) (Lenne and Wood, 1991).

The fungus Pyrenophora tritici-repentis (Died) Drechs. (anamorph Drechslera tritici-repentis (Died) Shoemaker) causes tan spot, a wheat foliage disease that occurrs worldwide causing significant yield losses (Hosford, 1982). The fungus produces lens-shaped tan necrotic lesions with a chlorotic halo on leaves of susceptible wheat cultivars (Hosford, 1971). Lamari and Bernier (1989) identified two lesion types with distinct symptoms, necrosis or chlorosis, produced by the fungus on appropriate wheat differential genotypes. Based on these two distinct symptoms, P. triticirepentis isolates have been grouped into eight races (Lamari and Bernier 1989; Lamari et al., 2003). Of these eight races, races 1 through 5 are present in the US (Ali and Francl, 2003; Engle et al., 2006). P. tritici-repentis produces hostspecific toxins that are associated with fungal pathogenicity and/or virulence (Balance et al., 1989; Brown and Hunger, 1993; Effertz et al., 1998; Tomas and Bockus, 1987; Touri et al., 1995). In addition, the toxins have been correlated to the development of the necrotic or chlorotic symptoms found on wheat differentials (Lamari and Bernier, 1989; Orolaza et al., 1995).

Historically, $P$. tritici-repentis was observed and reported on quackgrass (Agropyron repens) (Diedicke, 1902); but he did not test the fungus from this host to determine if it 
was pathogenic on wheat. However, other studies indicate that $P$. tritici-repentis is pathogenic on several wild relatives of wheat, including smooth bromegrass (B. inermis Leyss.), intermediate wheatgrass [T. intermedium (Host) Barkworth \& D.R. Dewey], western wheatgrass [P. smithii (Rydb.) Barkworth \& D.R. Dewey], crested wheatgrass [ $A$. cristatum (L.) Gaertn], and green needlegrass (S. viridula Trin.) (Drechsler, 1923; Hosford, 1982; Howard and Morall, 1975; Krupinsky, 1992b). The fungal isolates obtained from grasses and wheat were able to infect both wheat and grasses, irrespective of the isolate's host origin (Hosford, 1971; Howard and Morall, 1975; Krupinsky, 1987 and 1992a). In contrast, $P$. tritici-repentis isolates recovered from various grass species were found to be avirulent on wheat (Ali and Francl, 2003). However, all these studies except one (Ali and Francl, 2003) were conducted when the role of host-specific toxins in disease development and the race structure of the fungal populations was not well documented (Ali and Francl, 2003; DeWolf et al., 1998; Lamari et al., 2003).

The interaction between $P$. tritici-repentis and Great Plains grass populations includes its effect on these grasses and the economics of their uses as biomass and wildlife habitats as well as its ecomomic impact on wheat and the dynamics of tan spot epidemiology. In addition to the uncultivated grassland prairie populations, many grasses are utilized for pastures, soil reclamation, wildlife habitats, and windbreaks around agronomic crops in the northern Great Plains (Hass et al., 1997). In addition to contributing to the tan spot inoculum in wheat fields, susceptibility of noncereal grasses, especially those utilized in pastures, could lead to reduction in the yield and quality of the pasture biomass similar to damage caused by other foliar diseases (Elliot, 1961; Zeiders et al., 1986). These grasses need to be tested for their reactions to $P$. tritici-repentis races obtained from both wheat and grass hosts to provide a better understanding of the various host-pathogen interactions and their impact on the economics of pasture and other grass habitats as well as their impact on wheat.

In the present study, the reactions of five non-cereal grass host species, intermediate wheatgrass, smooth bromegrass, green needlegrass, crested wheatgrass, and western wheatgrass, were tested for their reaction to $P$. tritici-repentis races (1, 2, 3, 4 and 5) and two host-specific toxins, Ptr ToxA and Ptr ToxB.

\section{Materials and Methods}

Seedling production. Seedlings of all five grass species were raised in $16.5 \mathrm{~cm}$ deep and $3 \mathrm{~cm}$ wide tapered containers as described by Ali and Francl (2001). The five grass species were: crested wheatgrass (Agropyron cristatum) cultivars Nordan, Hycrest, Kirk, Parkway and Ruff; smooth bromegrass (B. inermis) cultivars Lincoln, Carlton, Barton, Saratoga, Rebound, Radison, and Badger; western wheatgrass (P. smithii) cultivars Rodan, Flintlock, Walsh, and ND-WWG931; green needlegrass ( $S$. viridula) cultivars Lodorm and SD-93; and. intermediate wheatgrass (T. intermedium) cultivars Reliant, Manska, Oahe, Clark, Chief, and Slate. Seed of these grasses were provided by Dr. Berdahl, USDA, Northern Great Plains Research Center, Mandan, ND. Four wheat genotypes: ND495 (susceptible to race 1 and Ptr ToxA sensitive); 6B365 (susceptible to race 1 and race 3); Katepwa (susceptible to race 1 exhibiting necrosis, race 5 exhibiting cholorosis, Ptr ToxA exhibiting necrosis, and Ptr ToxB exhibiting chlorosis); and M-3 (resistant to all five currently described and prevalent races in the US) were included for comparison. One singlespore isolate (SM19) of Pyrenophora bromi was included in as a positive control when smooth bromegrass cultivars were tested.

Fungal isolates, inoculum production and inoculations. Thirty single-spore isolates representative of $P$. triticirepentis (races 1-5), recovered from wheat and grass hosts, were selected randomly to test their pathogenicity on the five grass species (Table 1). The reaction of wheat differential genotypes to $P$. tritici-repentis races 1 to 5 are availble at http://tinyurl.com/nr5dszs. The isolates used in this study were previously obtained from wheat, durum (Triticum $d u$ rum Desf.), and non-cereal grasses for their race characterization (Ali and Francl, 2003) and stored as dried mycelial plugs at $-20^{\circ} \mathrm{C}$ (Jordhl and Francl, 1992).

Twenty-one seedlings of each genotype raised in seven containers (three seedlings/container) were inoculated at the 2- to 3-leaf stage with a individual fungal isolate from the thirty isolates listed above. The inoculum and inoculations were carried out as described in Ali and Francl (2001). Briefly, individual seedlings were inoculated by spraying with a spore suspension $(3,000$ spores $/ \mathrm{ml})$ from one of the $P$. tritici-repentis isolates until fluid ran off the plant. Thereafter, the seedlings were placed in humidity chambers at $100 \%$ humidity for $24 \mathrm{~h}$. The humidity period was employed to parallel protocols utilized by prior researchers in their $P$. tritici-repentis fungal isolates race characterization and in their genetic and cultivar evaluations against tan spot (Ali and Francl, 2003; Effertz et al., 2001; Faris et al., 1997; Lamari and Bernier, 1989 and 1994; Riede et al., 1996). Following the humidity chamber, they were moved to a growth chamber set at $21^{\circ} \mathrm{C} / 18^{\circ} \mathrm{C}$ with $16 \mathrm{~h}$ 
Table 1. Origin of Pyrenophora tritici-repentis isolates tested for their reactions on crested wheat grass, green needlegrass, intermediate wheatgrass, smooth bromegrass, and western wheatgrass

\begin{tabular}{|c|c|c|c|}
\hline Race & $\#$ of isolates & Source & Place of collection \\
\hline 1 & 11 & $\begin{array}{l}\text { Spring wheat (8), winter wheat (2) smooth brome- } \\
\text { grass (1) }\end{array}$ & Argentina (1), Canada (1), Uruguay (1), USA (8) \\
\hline 2 & 3 & Spring wheat & Canada (1), Uruguay (1), USA (1) \\
\hline 3 & 1 & Durum & Canada \\
\hline 4 & 13 & $\begin{array}{l}\text { Spring wheat (2), winter wheat (1), intermediate } \\
\text { wheatgrass ( } 6) \text {, smooth bromegrass ( } 2) \text {, Altai wheat- } \\
\text { grass ( } 2)\end{array}$ & Canada (1), USA (12) \\
\hline 5 & 2 & Durum & USA \\
\hline $\begin{array}{c}\text { Total } \\
\text { isolates }\end{array}$ & 30 & & \\
\hline
\end{tabular}

light and $8 \mathrm{~h}$ dark cycle. Seedlings were rated 8 days postinoculation using the rating scale 1-5 (Lamari and Bernier, 1989) where 1-2 is resistant to moderately resistant, 3 is moderately suceptible and 4-5 are susceptible. Leaves of all inoculated genotypes described earlier were clipped 10 days post-inoculation for fungal recovery. Isolations were made as described by Ali and Francl (2001) except 30-40 leaf segments were used instead of 45-50 segments.

Reaction of the five alternate hosts plants to Ptr ToxA and Ptr ToxB. All genotypes of the five alternate hosts were tested for their reaction to Ptr ToxA and Ptr ToxB by infiltrating purified Ptr ToxA $(10 \mu \mathrm{g} / \mathrm{ml})$ or a diluted Ptr ToxB culture filtrate $(1 \mathrm{ml}$ of culture filtrate $/ 9 \mathrm{ml}$ of distilled sterilized water) on separate leaves (Orolaza et al., (1995). Toxin was infiltrated as described by Faris et al., (1996). Ten leaves (fully expanded second leaf) of each genotype were infiltrated with each toxin at the two-leaf seedling stage. Wheat genotypes ND495 (Ptr ToxA sensitive), Katepwa (Ptr ToxA and Ptr ToxB sensitive), and M-3 (insensitive to both Ptr ToxA and Ptr ToxB) were included in the experiment as checks. Sterilized distilled water and diluted Fries medium were also infiltrated into all the genotypes as additional controls. After infiltration, the plants were kept in a growth chamber at $21^{\circ} \mathrm{C}$ during the day and $18^{\circ} \mathrm{C}$ at night with $16 \mathrm{~h}$ photoperiod until they were rated for their reaction 6 days later. The experiment was repeated once.

\section{Results and Discussion}

Reaction of the five non-cereal species to $P$. triticirepentis races $1-5$. All twenty-four cultivars of five noncereal grasses exhibited resistant reactions to all 30 isolates utilized in this experiment, as they primarily developed type 1lesions with infrequent type 2 lesions (Table 2, Figs. $1 \mathrm{a}$ and $\mathrm{b}$ ). For the wheat genotypes tested, ND495 and Katepwa developed tan necrosis to race 1 and 2 isolates.; 6B365 developed extensive chlorosis to races 1 and 3; and Katepwa exhibited extensive chlorosis to race 5 isolates.

Table 2. Reaction of five non-cereal grasses to five races and two host-specific toxins of Pyrenophora tritici-repentis

\begin{tabular}{lcccccccc}
\hline \multirow{2}{*}{ Grass species } & \multicolumn{9}{c}{ Reaction $^{\mathrm{a}}$} & & \multicolumn{2}{c}{ Host-specific toxins $^{\mathrm{b}}$} \\
\cline { 2 - 4 } & Race1 & Race2 & Race3 & Race4 & Race5 & & Ptr ToxA & Ptr ToxB \\
\hline Crested wheatgrass & $1-2$ & $1-2$ & $1-2$ & 1 & $1-2$ & & Insensitive & Insensitive \\
Smooth bromegrass & $1-2$ & $1-2$ & $1-2$ & 1 & $1-2$ & & Insensitive & Insensitive \\
Western wheatgrass & $1-2$ & $1-2$ & $1-2$ & 1 & $1-2$ & & Insensitive & Insensitive \\
Green needlegrass & $1-2$ & $1-2$ & $1-2$ & 1 & $1-2$ & & Insensitive & Insensitive \\
Intermediate wheatgrass & $1-2$ & $1-2$ & $1-2$ & 1 & $1-2$ & & Insensitive & Insensitive \\
\hline
\end{tabular}

${ }^{a}$ Reaction types based on a 1-5 scale derived by Lamari and Bernier (1989). Lesion type 1 and 2 signify resistance (R).

${ }^{b}$ Purified Ptr ToxA was provided by Dr. Steve Meinhardt, Department of Biochemistry, NDSU. Culture filtrates of Ptr ToxB was obtained from isolate DW7 as described by Orolaza et al. (1995) Insensitive reactions indicate no necrosis or chlorosis was developed on Ptr ToxA or Ptr ToxB infiltation. 

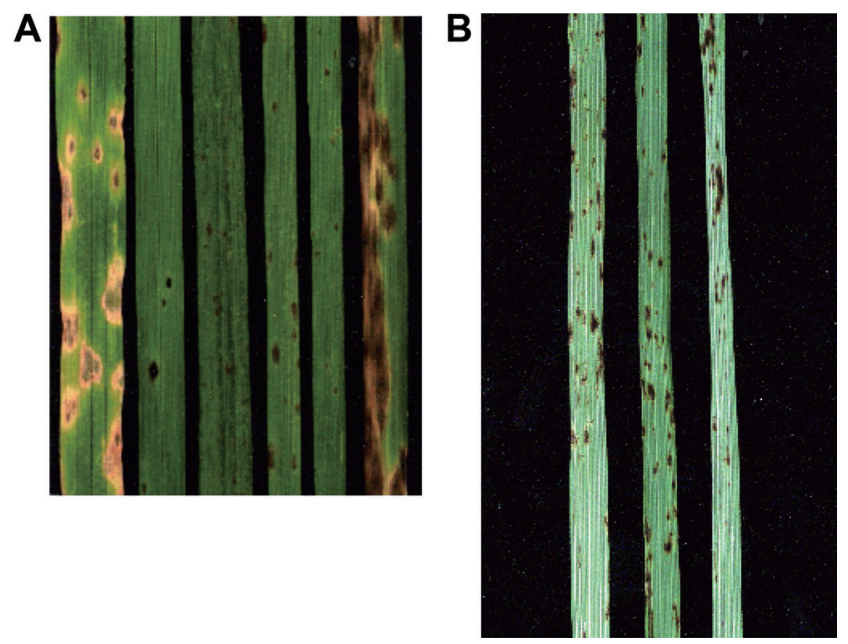

Fig. 1. (A) (L-R). Reaction of two wheat genotypes, (ND495 and $\mathrm{M}-3$ ), and three non cereal grasses [smooth bromegrass (Badger), intermediate wheatgrass (Clark), and crested wheatgrass (Parkway)] to Pyrenophora tritici-repentis race 1 isolate Pti2. Extreme right, smooth bromegrass (Badger) inoculated with P. bromi isolate SM 18A. (B) (L-R). Reaction of two western wheatgrass genotypes Rodan and Lodorum, and one green needlegrass genotype SD93 to Pyrenophora tritici-repentis race 1 isolate Pti2.

M-3 developed lesion types 1 or 2 (resistant to moderately resistant) to all isolates tested. The reaction of races 1-5 observed on the wheat genotypes verified the virulence and successful inoculations of all isolates.

The results of this study are contradictory to the previous studies where smooth bromegrass, intermediate wheatgrass, western wheatgrass, crested wheatgrass, and green needlegrass were found as susceptible as wheat to $P$. triticirepentis (Hosford, 1971; Krupinsky 1982; Krupinsky, 1986). These contradictory results may be due to differences in the virulence of the fungal isolates used in the different studies. Also, detached leaf bioassay was used in most previous isolate evaluations. In this bioassay, heavy spore loads placed directly on one site of the leaf segments under high humidity may provide conditions for disease development or tissue necrosis that are not representative of field situations and lead to inaccurate conclusions. For example, 23 isolates of $P$. tritici-repentis tested by Hosford (1971) did not induce any symptoms on Russian wild rye. However, in another study, Russian wild rye was ranked second to wheat in susceptibility to $P$. tritici-repentis. (Krupinsky, 1982). Krupinsky (1987) tested 27 P. tritici-repentis isolates from smooth bromegrass on wheat and smooth bromegrass. All the smooth bromegrass isolates tested produced symptoms on wheat and smooth bromegrass; however, isolates recovered from smooth bromegrass varied in virulence, which correlated with the different symptoms they induced. In another study, Ali and Francl (2003) tested 92 isolates recovered from various non-cereal grasses including smooth bromegrass, intermediate wheatgrass, and crested wheatgrass leaf samples collected from national grasslands, state parks, and national parks. All isolates did not produce any symptoms on wheat. Later research indicated that smooth bromegrass and other non-cereal grasses may have a different $P$. tritici-repentis population (Ali and Francl, 2003). In another study, quackgrass (Agropyron species) was rated as immune to $P$. tritici-repentis isolates obtained from Belgium (Maraite et al., 1992). Moreover, the symptoms incited by $P$. tritici-repentis were not observed on non-cereal grasses present around the severely infected tan spot wheat fields (Maraite et al., 1992). The results here are in agreement with Maraite et al., (1992) as crested wheatgrass and western wheatgrass, members of Agropyron were resistant to all five currently identified races in North America. All seven smooth bromegrass genotypes developed brown leaf spots to P. bromi (Fig. 1a). These results are in agreement with the previous studies (Berg and Sherwood, 1994; Zeider et al., 1986) that the majority of tested smooth bromegrass cultivars, including Lincoln, Saratoga, and Radisson, were susceptible to $P$. bromi.

Recovery of $\boldsymbol{P}$. tritici-repentis from inoculated grasses. The fungus could not be recovered from any non-cereal grass cultivar green leaf pieces with lesion type 1 or 2 . However, the fungus was recovered from dried or senescent leaf pieces infrequently (Fig. 2). The recovery of the fungus from senescent or dried leaf portions may be expected as the fungus can survive as a saprophyte or may be dormant in moderately-resistant genotypes until tissue senesces. The fungus was recovered from inoculated leaves of all wheat genotypes that exhibited susceptible reactions. There were few senescent or dried wheat leaves, as the inoculated leaves were still green when rated. These results contrast to previous studies where the fungus was recovered from the inoculated leaves of smooth bromegrass, intermediate wheatgrass, quackgrass, and western wheatgrass (Hosford, 1971; Krupinsky, 1982). This discrepancy may be due to the differences in the cultivars and isolates used during this study and previous studies. In previous studies, the cultivars used in the experiment exhibited susceptible reactions. It was possible to recover the fungus from those susceptible grasses, as the fungus was recovered from susceptible wheat genotypes but not the resistant one in this current study. Krupinsky (1982) attempted to re-isolate $P$. tritici-repentis from inoculated leaves of various non-cereal 


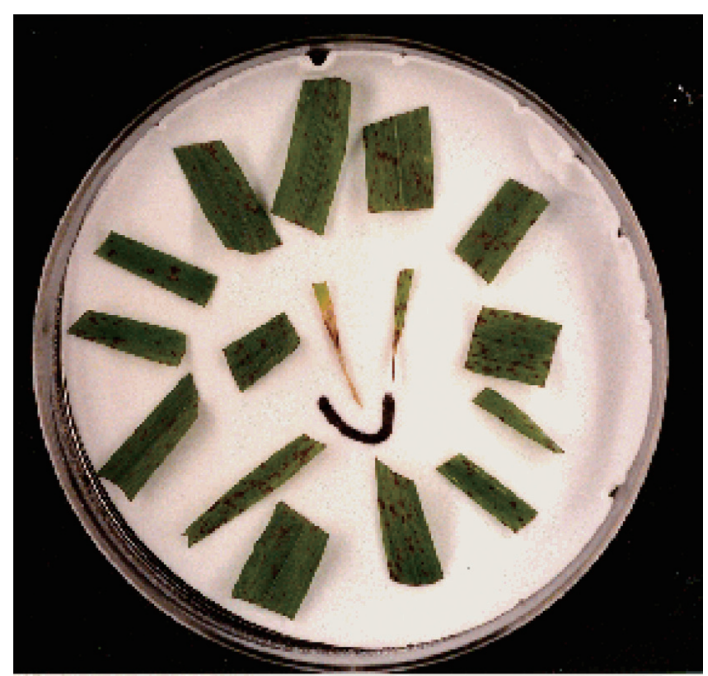

Fig. 2. Crested wheatgrass cultivar "Park" leaf pieces artificially inoculated with Pyrenophora tritici-repentis race 1 isolate Pti2. The fungus was recovered only from the leaf tips marked with a black marker.

grasses and observed variation in the fungal recovery among the grass species. Sand reed and switchgrass harbored the least amount of fungus. The same two grass species were also the least susceptible to the fungus. It indicated that the $P$. tritici-repentis may not be establishing in the moderately resistant or resistant grass species; thus, making the fungal recovery difficult. This may also have occurred in our study, as all grass species tested were resistant. In the present study, the inoculated leaves were clipped 7 days after inoculation, placed directly on moistened Whatman filter paper $\# 1$ and incubated for $24 \mathrm{~h}$ at $22^{\circ} \mathrm{C}$ under light and $24 \mathrm{~h}$ at $16^{\circ} \mathrm{C}$ in dark. The fungus was recovered from almost all the leaf pieces of susceptible wheat genotypes but not from the leaf pieces of non-cereal grasses. A $48 \mathrm{~h}$ incubation period and green leaf pieces for isolation were utilized to maxize the likelihood of fungal recovery especially for a facultative saprophytic fungus.

Reaction of host-selective toxins. The wheat genotypes, ND495 and Katepwa, developed necrosis to Ptr ToxA; whereas, Katepwa developed chlorosis to Ptr ToxB. Wheat genotypes, 6B365 and M-3, did not develop any symptoms to the toxins. The reaction of differential wheat genotypes used as checks to the toxins verified the infiltration process and effectiveness of the toxins.

All 24 cultivars of the five non-cereal grasses failed to develop necrosis to Ptr ToxA (Fig. 3) or chlorosis to Ptr ToxB. These results were expected as all the five grass spe-

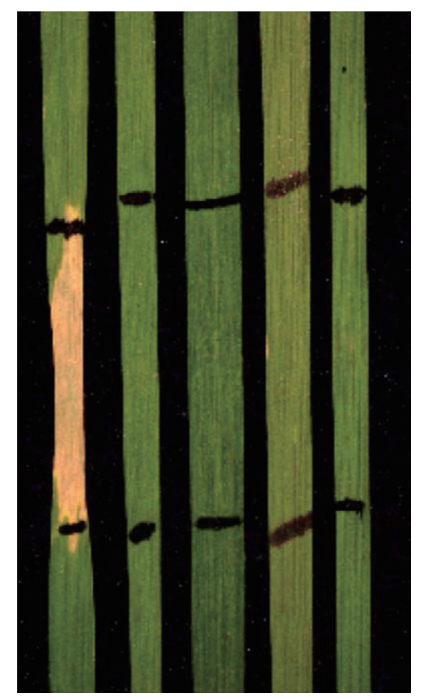

Fig. 3. (L-R). Reaction of two wheat genotypes (ND495 and M-3) and three non-cereal grasses [smooth bromegrass (Badger), intermediate wheatgrass (Clark), and crested wheatgrass (Parkway)] to host-specific toxin Ptr ToxA.

cies showed resistance to the fungal isolates of races 1,2 , and 5, which produce the toxins, and these toxins are associated with fungal pathogenicity/virulence (Ciuffetti et al., 1999; Lamari and Bernier, 1989). Insensitivity of these five non-cereal grasses to the toxins strengthens our conclusion that these grasses are very resistant or may be non-hosts to races of $P$. tritici-repentis virulent on wheat.

\section{Conclusion}

The resistant reaction to fungal inoculation, the insensitivity to two host-specific toxins, and the minimal recovery of the pathogen from leaves of intermediate wheatgrass, crested wheatgrass, green needlegrass, smooth bromegrass, and western wheatgrass is evidence that these hosts may have a limited or nonsignificant role in the epidemiology of tan spot on wheat in the Great Plains. Also, these five species can apparently be grown in areas where wheat is cultivated without having a potential negative effect on their pasture biomass and habitat quality due to tan spot. However, the fungal population may gradually become adapted to noncereals if large acreages of these grasses are grown in the vicinity of wheat production due to selction pressure. Additionally, these grass species with their resistant reactions represent a potential pool of resistance genes that could be valuable in the improvement of wheat cultivars. More research to evaluate and identify these genes remains a future goal of this research. 


\section{References}

Ali, S. and Francl, L. J. 2003. Population race structure of Pyrenophora tritici-repentis prevalent on wheat and non-cereal grasses in the Great Plains. Plant Dis. 87:418-422.

Ali, S. and Francl, L. J. 2001. Recovery of Pyrenophora triticirepentis from barley and reaction of 12 cultivars to five races and two host-specific toxins. Plant Dis. 85:580-584.

Ballance, G. M., Lamari, L. and Bernier, C. C. 1989. Purification and characterization of a host selective toxin from Pyrenophora tritici-repentis. Physiol. Mol. Plant Pathol. 35:203213.

Berg, C. C. and Sherwood, R. T. 1994. Stability of resistance to leaf disease in orchardgrass and smooth bromegrass germplasms. Crop Sci. 34:1495-1498.

Brown, D. A. and Hunger, R. M. 1993. Production of a chlorosisinducing, host-specific, low-molecular weight toxin by isolates of Pyrenophora tritici-repentis, cause of tan spot of wheat. J. Phytopathol. 137:221-232.

Ciuffetti, L. M. and Tuori, R. P. 1999. Advances in the characterization of the Pyrenophora tritici-repentis-wheat interaction. Phytopathology 89:444-449.

De Wolf, E. D., Effertz, R. J., Ali, S. and Francl, L. J. 1998. Vistas of tan spot research. Can. J. Plant Pathol. 20:349-444.

Diedicke, H. 1902. Uber den Zusammenhang zwischen Pleospora- und Helminthosporium- arten. Centrablatt fur Bakteriologie und Parasitenkunde Jena, Abt. 9:317-329.

Dinoor, A. 1974. Role of wild and cultivated plants in the epidemiology of plant diseases in Israel. Annu. Rev. Phytopathol. 12:413-436.

Drechsler, C. 1923. Some graminicolous species of Helminthosporium. I. J. Agri. Res. 24:614-670.

Effertz, R. J., Anderson, J. and Francl, L. J. 1998. QTLs associated with resistance to chlorosis in adult wheat. Can. J. Plant Pathol. 20:438-439.

Elliott, E. S. 1961. Disease damage in forage grasses. Phytopathology 52:448-451.

Engle, J. S., Madden, L. V. and Lipps, P. E. 2006. Distribution and pathogenic characterization of Pyrenophora tritici-repentis and Stagonospora nodorum in Ohio. Phytopathology 96: 1355-1362.

Faris, J. D., Anderson, J. Francl, L. J. and Jordahl, J. G. 1996. Chromosomal location of a gene conditioning insensitivity in wheat to a necrosis-inducing culture filtrate from Pyrenophora tritici-repentis. Phytopathology 86:459-463.

Francl, L. J. and Jordahl, J. G. 1994. Refined procedures for inoculating wheat seedlings with Pyrenophora tritici-repentis and rating their reactions. Plant Dis. 78:745-748.

Hass, J. R., Sedivec, K. K. and Tober, D. A. 1997. Grass varieties for North Dakota. North Dakota State University Extension Service, Fargo, 16 pp.

Hosford, R. M. 1971. A form of Pyrenophora trichstoma pathogenic to wheat and other grasses. Phytopathology 61:28-32.

Hosford, R. M. 1982. In: Tan spot - developing knowledge 1902-
1981, virulent races and wheat differentials, methodology, rating systems, other leaf diseases, literature. ed by R. M. Hosford, pp. 1-20. Tan Spot of Wheat and Related Disease Workshop. Fargo, ND: North Dakota Agric. Exp. Station.

Howard, R. J. and Morrall, R. A. A. 1975. The epidemiology of leaf spot disease in a native prairie. I. The progression of disease with time. Can. J. Bot. 53:1040-1050.

Jordahl, J. G. and Francl, L. J. 1992. In: Increase and storage of cultures of Pyrenophora tritici-repentis. eds. by L. J. Francl, J. M. Krupinsky, and M. P. McMullen, p. 109. Advances in Tan Spot Research. Fargo, ND: North Dakota Agric. Exp. Station.

Krupinsky, J. M. 1982. Observation of the host range of isolates of Pyrenophora trichostoma. Can. J. Plant Pathol. 4:42-46.

Krupinsky, J. M. 1986. Pyrenophora tritici-repentis, P. bromi, and Leptosphaeria nodorum on Bromus inermis in the Northern Great Plains. Plant Dis. 70:61-64.

Krupinsky, J. M. 1987. Pathogenicity on wheat of Pyrenophora tritici-repentis isolated from Bromus inermis. Phytopathology 77:760-765.

Krupinsky, J. M. 1992a. Aggressiveness of isolates of Pyrenophora tritici-repentis obtained from wheat in the northern great plains. Plant Dis. 76:87-91.

Krupinsky, J. M. 1992b. Grass hosts of Pyrenophora triticirepentis. Plant Dis. 76:92-95.

Krupinsky, J. M. and Berdhal, J. D. 1984. Evaluation of Agropyron intermedium for reactions to various leaf spot diseases. Plant Dis. 68:1089-1091.

Lamari, L. and Bernier, C. C. 1989. Virulence of isolates of Pyrenophora tritici-repentis on 11 wheat cultivars and cytology of the differential host reactions. Can. J. Plant Pathol. 11:284290.

Lamari, L., Strelkov, S. E., Yahyaoui, A., Orabi, J. and Smith, R. B. 2003. The identification of two new races of Pyrenophora tritici-repentis from the host center of diversity confirms a one-to-one relationship in tan spot of wheat. Phytopathology 93:391-396.

Lamari, L., R., Boulif, S. M. and Bernier, C. C. 1995. Identification of a new race in Pyrenophora tritici-repentis: Implications for the current pathotype classification system. Can. J. Plant Pathol. 17:312-318.

Lenne, J. M. and Wood, D. 1991. Plant diseases and the use of wild germplasm. Annu. Rev. Phytopathol. 29:35-63.

Mankin, C. J. 1969. Diseases of cereals and grasses in South Dakota. South Dakota Agric. Exp. Stn. Tech. Bull. 35. Brookings, SD: South Dakota Agri. Exp. Station.

Maraite, H., Berney, J. F. and Goffin, A. 1992. In: Epidemiology of tan spot in Belgium. eds. by L. J. Francl, J. M. Krupinsky, and M. P. McMullen, pp. 73-79. Advances in Tan Spot Research. Fargo, ND: North Dakota Agri. Exp. Station.

Mitra, M. 1934. A leaf spot disease of wheat caused by Helminthosporium tritici-repentis Died. Indian J. Agric. Sci. 4:692700.

Nisikado, Y. 1928. Preliminary notes on yellow leaf spot diseases of wheat caused by Helminthosporium tritici-vulgaris Nisi- 
kado. Inst. Agric. Biol. 4:103-109.

Orolaza, N. P., Lamari, L. and Balance, G. M. 1995. Evidence of a host-specific chlorosis toxin from Pyrenophora triticirepentis, the causal agent of tan spot of wheat. Phytopathology $85: 1282-1287$.

Platt, H. W. 1978. Factors affecting spore production and liberation of Pyrenophora tritici-repentis (Died.) Drechs. Ph.D. Thesis. University of Saskatchwan.

Shoemaker, R. A. 1962. Drechslera Ito. Can J. Bot. 40:809-836.

Sprague, R. 1950. Diseases of cereals and grasses in North America. New York: Ronald Press Co..

Tomás, A. and Bockus, W. W. 1987. Cultivar specific toxicity of culture filtrate of Pyrenophora tritici-repentis. Phytopathology 77:1337-1366.

Tuori, R. P., Wolpert, T. J. and Ciuffetti, L. M. 1995. Purification and immunological characterization of toxic components from cultures of Pyrenophora tritici-repentis. Mol. PlantMicrobe Interact. 8:41-48.

Valder, P. G. and Shaw, D. E. 1952. Yellow spot disease of wheat in Australia. Proce. Linn. Soc. N.S.W. 77:323-330.

Zeiders, K. E., Sherwood, R. T. and Berg, C. C. 1986. Reaction of smooth bromegrass accessions to brown leaf spot caused by Pyrenophora bromi. Plant Dis. 70:324-326. 